\title{
ФИЛОСОФИЯ
}

DOI: https://doi.org/10.15688/lp.jvolsu.2019.3.1

UDC 124.3

LBC 87.21

\section{ON THE NEED TO REVISE APPROACHES TO THE INTERPRETATION OF TELEOLOGY}

\author{
Alexander V. Petrov \\ Omsk Academy of the Ministry of Internal Affairs of the Russian Federation, Omsk, Russian Federation
}

\begin{abstract}
Modern philosophy pays much attention to complex self-evolving systems that cannot be satisfactorily described solely by causal explanation ignoring the potential of a teleological approach that emphasizes the expediency of phenomena. The tendencies to interdisciplinarity and closer interaction of natural Sciences and Humanities being characteristics of postnonclassical rationality stipulate critical reception of the problem of expediency. The history of the problem of teleology shows it to be a problem with a damaged reputation, since the problem of total goals has been stigmatized since the establishment of mechanicalism. In the eyes of scientism teleology is discredited by fatalism, conservatism, and finalism, which evoke distinct associations with religious eschatology. Teleology as a strategy of thought is indeed marginal and fruitless - but only within the natural Sciences, in which the opposite of the target causal explanation has proved effective. Determinism avoids paying attention to the problem of the goal - to the extent that it seeks to declare it fictitious and meaningless. In the humanitarian sphere the situation is different, since it is quite appropriate to assume the possibility of their purposefulness with respect to the phenomena of the world of culture. The problem of purposefulness can count on the restoration of reputation, since the target determination in the phenomena of culture makes itself felt no less than the causal determination. For its disclosure the article introduces three types of teleology - sacred, secular and vital. Culture and social reality as a whole are subject to teleological causality as far as they can be understood as narratives. The creative transformation of the world is determined by questioning, tradition and goal-setting, which makes it possible to look for teleological accents in it, because the interpretation of the phenomena of cultural space depends on them.
\end{abstract}

Key words: teleology, causal explanation, sacred teleology, secular teleology, vital teleology.

УДК 124.3

ББК 87.21

\section{О НЕОБХОДИМОСТИ РЕВИЗИИ ПОДХОДОВ К ИНТЕРПРЕТАЦИИ ТЕЛЕОЛОГИИ}

\footnotetext{
Александр Викторович Петров

Омская академия МВД России, г. Омск, Российская Федерация 
репутацией, поскольку со времен утверждения механицизма проблема тотальных целей подверглась стигматизации. В глазах сциентизма телеологию дискредитируют фатализм, консерватизм и финализм, вызывающие отчетливые ассоциации с религиозной эсхатологией. Телеология как стратегия мышления действительно маргинальна и бесплодна - но только в пределах естественных наук, в которых доказало свою эффективность противоположное целевому причинно-следственное объяснение. Детерминизм избегает обращать внимание на проблему цели - вплоть до того, что стремится объявить ее фиктивной и лишенной смысла. В гуманитарной сфере дела обстоят иначе, поскольку относительно феноменов мира культуры вполне уместно допустить возможность их целенаправленности. Проблема целенаправленности может рассчитывать на восстановление репутации, поскольку целевая детерминация в феноменах культуры дает о себе знать ничуть не меньше, чем детерминация причинно-следственная. Для ее раскрытия в статье вводятся три типа телеологии - сакральная, секулярная и витальная. Культура и социальная реальность в целом подчиняются телеологической причинности настолько, насколько их можно понимать как нарратив. Творческое преобразование мира детерминируется вопрошанием, традицией и целеполаганием, что делает возможным искать в нем телеологические акценты, ведь именно от них зависит интерпретация феноменов культурного пространства.

Ключевые слова: телеология, причинно-следственное объяснение, сакральная телеология, секулярная телеология, витальная телеология.

Сколько бы философия ни утверждала в попытках самоосмысления тезис о том, что она - средоточие критического взгляда на вещи, - ее утверждения никогда не смогут избавиться от аксиоматического характера. Bce, что утверждает философия сейчас, утверждала ранее и будет утверждать в дальнейшем, так или иначе требует веры (как минимум, в собственную достоверность), хотя и доступно для аргументации и критики. Известный «догматизм» философии проявляет себя во многом - от тезиса о тождестве бытия и мышления, являющегося предметом горячих споров «идеалистов» и «материалистов» (позволим себе взять эти слова в кавычки как ярлыки, столь любимые в истории философии, и оставим за скобками вопрос о том, станет ли последовательный материалист опровергать взгляды, в его глазах малозначимые), до уверенности в том, что философия является наукой в строгом смысле слова. Даже сама мысль, высказанная в предыдущем предложении, требует веры в то, что история философии существует (т.е. может быть описана как история, а не как дискретная череда явлений) и что философия находится в некоторых отношениях с наукой и может быть определена относительно нее. Этому суждению можно противопоставить убедительные утверждения противоположного смысла, столь же догматичные и в то же время для критики (не наносящей им, однако, никакого вреда). Общеизвестна удивительная особенность философии быть убедительной, но значительно менее способной переубеждать - однаж- ды сформированная позиция (мировоззрение, стратегия мышления еtс.) весьма неохотно уступает место другой, даже под воздействием аргументов, безусловно убедительных в иных обстоятельствах (например, вне конфликта мнений). Мера доверия ко взглядам прямо зависит от того, насколько стратегия мышления, релевантная им, удовлетворяет запросам сознания - утверждает ли она принцип понятности мира, говорит что-либо об его человекоразмерности, обещает ли обнаружение смысла феноменов за пределами вещного мира и т. д. - словом, предлагает ли она систему координат и шкалу оценок, в которую хотел бы себя поместить и которой желал бы пользоваться человек. В этом философия похожа на религию - с той разницей, что последняя не только дает систему координат и шкалу оценок, но и однозначно указывает на их происхождение и неоспоримую ценность. Значительная часть философской проблематики вышла из религиозной сферы, и, хотя обрела она себя вне ее пределов, некоторые темы философии до сих пор имеют достойный внимания религиозный смысл. К их числу относится телеология.

Телеологическая проблематика является общей для философии и религии, причем в области последней телеология имеет большую содержательность. Религия невозможна без эсхатологии и сотериологии - векторов, имеющих отчетливый телеологический характер, проявляющий себя в утверждениях о тотальных целях и целях индивидуальных. Их описание конкретно: сотериология состав- 
ляет ядро религиозной антропологии и этики, а эсхатология ставит точку в раскрытии онтологии и завершает историю. Способность «завершать» и «закрывать»- важнейшая черта религиозной телеологии, которая, будучи распространенной за пределы религии в область философии, не только покусилась на автономию последней, но и дала обильную почву для упреков телеологии как таковой в финализме, отрицании свободы развития и отсутствии эвристического потенциала (последнее обусловлено использованием способа объяснения, обратного причинно-следственному). Эти обвинения убедительны постольку, поскольку такая стратегия мышления действительно маргинальна, бесплодна и непригодна - но только в пределах естественных наук. В гуманитарной сфере дела обстоят иначе. Выше уже шла речь о том, что от «принятия» определенной стратегии мышления зависит отношение к философским проблемам. Решение проблемы цели и сама возможность телеологии также зависят от этого.

История проблемы телеологии показывает ее темой с испорченной репутацией испорченной, прежде всего, в глазах науки. За то, что телеология с самого момента своего выхода в философское пространство не порывала связи с религиозным мировосприятием и в религиозной области имела значительно больше конкретности, чем где бы то ни было еще, философия со времен утверждения механицизма стигматизировала проблему тотальных целей. В отношении сциентизма к проблеме телеологии типично проявляют себя обвинения ее в финализме, фатализме, шире в консерватизме. Христианская телеология указывала на конечные цели бытия мира и человека - разумеется, с элиминацией религиозного аспекта философии, начавшегося еще в эпоху Возрождения, христианская интерпретация конечных целей оказывалась все менее убедительной. В итоге из науки, а затем и философского дискурса в большей части философских направлений была элиминирована не только проблема религиозной телеологии, но и проблема телеологии вообще.

Да и какая судьба могла ожидать точку зрения, столь разительно отличающуюся от идеала научности, утвердившегося в Новое время? Финализм телеологии, указывающий на возможность определения тотальных целей существования, вызывал отчетливые ассоциации с религиозной эсхатологией, что уже само по себе не было комплиментарно с точки зрения эпохи Просвещения с его протестом против клерикализма, феодализма и вообще всего, что имело отношение к «темным векам» (к этому впоследствии присоединился протест против креационизма, не испытывавший к телеологии ничего, кроме антипатии). Подозрения в фатализме, почвой для которых могут служить рассуждения о тотальных целях, также не могли существовать в одном пространстве с верой в разум, которой было проникнуто Новое время. Эта вера обещала человечеству освобождение от настроений общественной жизни, победу над голодом, болезнями и прочими скорбями, но главное - она вселяла надежду на обладание твердым знанием о мире, которое одно лишь может принести эти вожделенные плоды. Утопические социальные модели (от Т. Мюнцера до Н.Г. Чернышевского) представлялись настолько реализуемыми, что, казалось, наука может вернуть человечеству утраченный рай и преодолеть грехопадение, восстановить поврежденное достоинство тварного мира, созидателем которого сделается сам человек. В этом отношении показательна попытка организовать «рациолатрию» деистического толка вскоре после свержения французской монархии в XVIII в., вошедшая в историографию как Культ Разума [Олар web]. Эта попытка, на современный взгляд карикатурная, на первых порах даже встретила у современников живой отклик и была в общем симптоматичной для того времени. Очевидно, что свобода разума быть самим собой, утверждаемая секулярной культурой, выглядит значительно привлекательнее фатализма, который может быть обнаружен внутри телеологии.

Еще одним мотивом, компрометирующим телеологию, является консерватизм, который может найти в ней аргументы в свою пользу. Этот консерватизм проявляет себя в разных горизонтах - от абстрактно-спекулятивного до социального. Первый находит себе оправдание в религиозно подкрепленном провиденциализме и логически обоснованном универсализме (например, в виде рациональной теодицеи Фомы Аквината, построенной, 
среди прочего, на идее степеней совершенств, средоточие которых есть Бог [Фома Аквинский 2000, 209]). Второй заявляет о себе тогда, когда речь идет о финалистическом понимании истории и судьбах народов или общественных институтов, когда однажды наметившаяся траектория общественного развития представляется единственно правильной. Сейчас уместно вести речь о первом, поскольку консерватизм в познавательных установках нередко ассоциируется с обскурантизмом, хотя отождествлять их было бы ошибкой. Консерватизм уместнее отождествить с предрассудками - необходимо лишь определить, в каком смысле их следует понимать. Возможны два варианта отношения к ним, один из которых сводится к бэконовским idola fori и idola theatri (идол площади / рынка и идол театра), а другой - к герменевтике с характерным для нее видением в предрассудке основания и предпонимания, и самого познания [Гадамер 1991, 344]. Мысль о том, что предрассудки, олицетворяемые идолами, пагубны для познавательного процесса и препятствуют ему, вполне характерна для Нового времени. Нет никакой пользы ни от тех предрассудков, что «являются результатом неверных теорий или философских учений и ложных законов доказательства» [Бэкон 1977, 307], ни от тех, что «проникают в человеческий разум в результате молчаливого договора между людьми об установлении значения слов и имен» [Бэкон 1977, 309]. В телеологии обычно видят воплощение идола театра, что более чем оправданно, если понимать ее догматически и некритично. В этом случае она действительно представляет собой одну из «изобретенных философских систем... представляющих вымышленные и искусственные миры» [Бэкон 1978, 19].

Герменевтика в некоторой степени реабилитировала идолы площади, утверждая, что предрассудки невозможно элиминировать из структуры мышления постольку, поскольку они являются частью интенциональной основы языка. Впрочем, это не означает, что с ними совершенно ничего нельзя поделать. Г.-Г. Гадамер видел в дифференциации истинных и ложных предрассудков критическую задачу герменевтики, по мере решения которой предрассудки частного характера отмирают, а на авансцену выступают те, что обеспечивают истинное понимание. О значимости для познания традиции и предрассудков (если понимать их в смысле источника предпонимания и основания для интерпретации) красноречиво говорят эти строки: «Момент традиции в историко-герменевтическом поведении реализуется в форме общности основополагающих и несущих предрассудков - заранее сложившихся суждений. Герменевтика должна исходить из следующего: тот, кто хочет понять, связывает себя с предметом, о котором гласит предание, и либо находится в контакте с традицией, изнутри которой обращается к нам предание, либо стремится обрести такой контакт» [Гадамер 1991, 79]. Герменевтический подход к телеологии требует критического отношения к тем ее смыслам, которые имеют догматический характер и составляют ту часть ее исторического наследия, от которой стоит отказаться. Эта деликатная работа требует осмотрительности, поскольку вместе со списанием бесполезного исторического багажа можно незаметно дезавуировать и смыслы, которые могут оказаться полезными после переосмысления. Поскольку развитие социально-гуманитарных наук обеспечивается второй моделью отношения к предрассудкам (и, шире, к традиции и консерватизму), то становится очевидно, что действительный смысл упреков телеологии в консерватизме не выходит за пределы его социально-исторического понимания. Пример столь же узкого и тенденциозного подхода можно найти в отношении к религии, когда ее истинный портрет с тонкими онтологическими, гносеологическими и аксиологическими чертами заменяется маской, состоящей из исторических стереотипов, а к религиозным институтам подходят с политической или экономической меркой, считая все другие подходы для науки недопустимо прекраснодушными.

Как бы там ни было, мнимые или действительные финализм, фатализм и консерватизм телеологии все же являются второстепенными моментами, дискредитирующими ее в глазах сциентизма. Более существенным будет то обстоятельство, что в науке Нового времени утвердился и доказал эффективность познавательный принцип, противный телеологии, - речь идет о причинно-следственном объяснении. 
Категории причинности посвящен массивный корпус литературы - настолько значительный, что претендует либо на детальный разбор, либо допускает одно лишь упоминание - как тема, являющаяся общим местом. В контексте настоящей темы причинно-следственное объяснение допустимо назвать если не «телеологией наоборот», то реверсивным / обратным целеполаганием - допустимо в той мере, в какой использование причинно-следственного объяснения не приближает к решению проблемы понимания феноменов культуры. Очарованность возможностями причинно-следственного объяснения, воплотившаяся в классическом детерминизме, столкнулась со свободой, невозможной для него. Разбор мнений о том, какова может быть причинность и как возможно примирить ее со свободой, грозит стать самостоятельным и самоценным, поэтому ограничился здесь упоминанием современной концепции «свободной причинности», которая является попыткой включить в жесткие причинно-следственные связи нечто, привносящее смысл, но ориентированное совершенно противоположно, - цель.

Коротко говоря, В.Э. Терехович предлагает вместо действующей и целевой причинности, выделенных еще Аристотелем ${ }^{1}$, рассматривать «причинность вероятностную, а вместо детерминизма и телеологии интерференцию возможных движений» [Терехович $2012,57]$. Для нас важно, что целевая причинность, изгнанная из науки и философии сциентизмом, вновь признается достойной внимания - и цитируемым автором, и многими другими. Так, В.С. Степин утверждает, что понятие целевой причинности необходимо для понимания саморазвивающихся систем, для которых не хватает ни вероятностной причинности, ни тем более детерминизма ${ }^{2}$.

Не станем утверждать ничего насчет того, какой эвристический потенциал имеет понятие целевой причинности в естествознании и как он может быть реализован. В феноменах природы мы можем лишь усмотреть то, что И. Кант называл целесообразностью без цели, причины которой мы не можем в некоей воле [Кант 1994, 58], да и сама она («цель природы») лежит полностью за пределами способности суждения самой по себе [Кант 1994, 366]. В связи с этим принцип эко- номии мышления допускает лишь признание возможности такой целесообразности, не более того. Напротив, относительно феноменов мира культуры (шире - реальности сознания) уместно не только допустить возможность их целесообразности, но и предпринять попытку определить, какой она может быть. Иначе говоря, в отношении «физики» этот труд едва ли принесет плоды, тогда как для «лирики» он обещает быть весьма полезным.

Детерминизм, при всей своей силе и привлекательности, избегает обращать внимание на проблему цели - вплоть до того, что норовит объявить ее фиктивной и лишенной смысла. Основания для такого отношения вполне очевидны: во-первых, причинно-следственное объяснение удовлетворительно работает в предметных областях тех наук, что соответствуют сциентистскому идеалу научности, а во-вторых, о целях процессов, попадающих в их предметную область, нельзя сказать ничего не только общезначимого, но даже объективно-определенного. Бесплодность разговоров о целях в пределах сциентизма обусловила предвзятое отношение к проблеме цели как таковой, хотя истинные причины этого связаны с тем, что причинно-следственный подход не вполне адекватен природе явлений, уходящих корнями в мир сознания. Социально-гуманитарное знание давно утвердило свою методологическую автономию, реабилитировав и включив в поле зрения то, что отвергалось сциентизмом (например, предрассудки, вредные с точки зрения рациональности Нового времени, но весьма полезные для герменевтики). Представляется, что проблема целенаправленности может рассчитывать на такое же восстановление репутации, поскольку целевая детерминация в феноменах культуры дает о себе знать ничуть не меньше, чем детерминация причинно-следственная. Конечно, на это можно возразить, что целевая причинность - это возможность, а не действительность, как причинности действующая, материальная или формальная. Это так. Но если относительно естествознания ведутся разговоры о пользе свободной, вероятностной etc. причинности, то почему реальности и силы такой причинности нельзя утверждать относительно явлений культуры, в которых человек обладает максимумом свободы ${ }^{3}$ и ко- 
торую направляет не столько сообразно необходимости условий существования, сколько сообразно желаниям и возможностям, ориентированным целеполаганием?

В пользу небесплодности рассуждений о возможности поиска тотальных целей в бытии говорит то, что в мире сознания эти цели не только возможны, но и существуют в полной непреложности. Конечно, «мир идей» и «мир вещей» (или мир внеположенных сознанию явлений) не тождественны, но первый оказывает влияние на второй - и если характер этого влияния (и даже самой его возможности) является одной из основных философских проблем, то одна вещь соприсутствует в равной степени в обоих мирах, будучи и реальностью сознания, и одним из измерений внеположенного сознанию мира. В нем же существует и категория цели, всегда оставаясь возможностью. Речь идет о времени.

В современной картине мира понимание времени сохранило в себе некоторые рудиментарные черты исторически более ранних типов мировоззрения - начиная с обыденного идиллического представления о добротных былых временах и худородной современности, легко объяснимого психологически ${ }^{4}$, заканчивая фундаментальным тезисом о том, что время нашей Вселенной имеет точку отсчета. Начальное время - это момент старта космогонии, как ее понимает современная наука, и пора сакральных событий любой развитой религии. Если идея того, что время имеет начало, нашла себе место в научной картине мира, то идея его целенаправленности не покинула пределов мира культуры.

Известно, что в пределах религиозного мировоззрения впервые заявила о себе идея наличия целей истории, возможная, в свою очередь, благодаря идее конечности времени. Религиозная онтология - и религиозное понимание времени - имеют в виду тотальные цели и тотальное время, утверждать чтолибо о личном времени и целях личного бытия можно только лишь относительно этой тотальности. Впрочем, в объективном смысле и сама эта тотальность относительна настолько, насколько относительны религиозные максимы. Философская антропология со времен Протагора и Сократа делала акцент на человекоразмерности бытия; на этом его ка- честве зиждется способность сознания свободно устанавливать личные цели и делать высказывания нерелигиозного характера относительно тотальных целей. Философия первая претендующая на автономию форма секулярной культуры (что не предполагает, однако, полного разрыва с религиозной традицией; уместно вспомнить высказывание А. Кожева, говорившего так: «Хотим мы того или нет, зачинатели современной науки не были ни язычниками, ни атеистами, ни, как правило, даже антикатоликами» [Кожев 2006, 422]). Тем не менее, в этой секулярной культуре нашла себе место религиозная по генезу идея телеологии в онтологии - в виде телеологии, основанной на способности сознания свободно полагать цели своего существования. Общей чертой религиозной и секулярной телеологий является мысль о том, что категория цели проявляет себя там, где есть место процессу, управляемому субъектом, привносящим в него осмысленность. Если это воздействие гетерономно, а его источник имеет трансцендентальный характер, то телеологию, существующую на этом фундаменте, можно назвать сакральной. Напротив, если субъект, свободно и автономно полагает цели процесca, в который вовлечен, а в религиозных максимах видит одну из форм интеллектуальной культуры, а не нечто, обладающее высшим авторитетом, то такую телеологию можно назвать секулярной.

Типичным примером секулярной телеологии можно считать незаметно превратившиеся в «светские религии» политические идеологии, особенно в том виде, в котором они бытовали в XX в., когда перестали быть подходами к пониманию власти и властных отношений и сделались маркерами самоидентификации в самом широком спектре - от взглядов на вопросы собственности и ее распределению до гендерных отношений и потребительских вкусов. Как видно, политические маркеры в XX в. приобрели те же черты, что и религиозная идентификация в Средние века или Новое время. Действительно, антипатия, по внешности мотивированная тем, что оппонент имеет иные взгляды по поводу богочеловечества Христа времен внутриевропейского альбигойского крестового похода против катаров, немногим отличается от «охоты на 
ведьм» времен маккартизма в США. Альбигойцы в глазах своих противников были исчадиями ада, поскольку покушались на все, что дорого сердцу доброго католика, и извращали дорогу ко спасению [Дунаев 2008, 83-84]. Коммунистическая угроза казалась на Западе столь же реальной и не менее устрашающей - только с поправкой на экономику, политику и социальное устройство; собственно, это и было одной из причин демонизации коммунистов [Schrecker 1999, 8] в годы холодной войны. Иными словами, сакральное и секулярное нередко проявляет в вопросах целей немало общего - как минимум то, что цели секулярного генеза могут стать объектами горячей веры и даже приобрести своих мучеников. По этой причине противоположностью сакральной телеологии, видящей личные и тотальные цели в регистре священного, будет витальная телеология, полагающая цель существования в нем самом. Если сакральная телеология гетерономна и трансцендентна, то витальная телеология полностью имманентна и аномийна.

В секулярную телеологию входит самая обширная группа целей, которая может быть описана в самых разных, но всегда конкретных выражениях. Это могут быть цели, обусловленные многообразными и подробно описанными ценностями, составляющие пирамиду А. Маслоу, а могут быть цели, восходящие к идее альтруизма в интерпретации О. Конта или к деонтологии категорического императива И. Канта. Сакральная телеология имеет большую содержательность, поскольку гетерономное и трансцендентное возможно изложить только с помощью символов и превращенных форм смысла, всегда неоднозначных и оставляющих простор для интерпретаций. Аномийная и имманентная витальная телеология имеет максимально объемно понимаемую, а потому минимально содержательную цель. Этот колоссальный объем позволяет ей быть конкретизированной самым различным образом - настолько разнообразно, насколько широко можно понимать цель существования, обеспечивающего жизнь. Однако в понятие витальной телеологии может быть включен не только гедонизм, видящий цель в наслаждении жизнью (если брать в расчет его вульгарное понимание), не отягощенной страданием (в чем и состоит его подлинный смысл, поскольку Эпикур, в котором с древности видели главного апологета гедонизма, полагал, что истинное удовольствие состоит в освобождении от страданий, а это, в свою очередь, означает отказ от непосредственного чувства удовольствия как предмета стремлений [Танхилевич 1926, 89]). Ее питают также современные тревоги за выживание человечества как вида, сохранение биосферы и предотвращение экоцида, а также вызовы со стороны трансгуманизма, когда само понятие «жизнь» обещает изменить свое содержание и сделаться зависимым от личного выбора того, какой из технологически доступных форм существования воспользоваться. Первые воплощаются в вере в спасительную силу технического прогресса, который принесет избавление от всего, что угрожает жизни (впрочем, очень немногие экологи могут поддержать это кредо [Bourg 2009, 61]). В этой вере снимается противопоставление искусственного (техники) и естественного (жизни) и проявляет себя витальная телеология, поскольку за верой в технологии скрывается ни что иное как отрицание «естественной конечности», которое, в свою очередь, неотделимо от отрицания «конечности человека», т.е. от жизнеутверждения. Трансгуманизм же, делая акцент на том, что жизнь - это далеко не только форма существования белковых тел, и понимает ее весьма широко, поскольку она должна сделаться тем, что зависит от личного выбора того, какой из технологически доступных форм существования воспользоваться, - апеллирует к универсальному моральному праву разумного существа решать этот вопрос самостоятельно. По этому поводу К. Эллиотт замечает: «Если вы решили стать роботом, информационным паттерном или любой другой разумной жизнью, вы можете рассчитывать, что трансгуманисты будут защищать ваше благополучие» [Elliott 2003, 16].

Современный культурный ландшафт позволяет обнаружить на нем проявления телеологий всех трех типов - сакральной, секулярной и витальной. Целеполаганием сакрального характера объясняются не только традиционные или ритуальные действия, актуально или ретроспективно связанные с культовой практикой, но и готовность умирать за свою веру. Так, сделавшиеся пугающей частью 
современной информационной мозаики шахиды, из чего-то экстраординарного ставшие рутинной деталью Сирийской войны последних лет (настолько характерной, что вошли в сюжет компьютерной игры-стратегии, посвященной этим событиям), не могут быть поняты иначе, чем через призму целей радикального ислама, требующего убийства неверных и обещающего за это спасение. Сакральная телеология помещает цель в вечность, в инобытие, трансцендирование к которому может быть одномоментным (и столь же далеким от всякой философии, сколь и ужасающим как в случае с шахидом), так и длиною в жизнь, аскетическим и преображающим (каков, например, путь к личной святости в христианской антропологии). Секулярная телеология проявляет себя на пестрой палитре современности чрезвычайно разнообразно - от политических целей, экономических доктрин или свободы гендерного самоопределения до свободы научного поиска, не желающего стесняться этикой - при всей широте спектра их объединяет одно: акцент на свободе выбора и самостоятельную ценность этих целей. Она локализует цели в более-менее отдаленной исторической перспективе, полагая их вполне достижимыми в будущем или требующими от каждого поколения и каждого человека жертвы в их пользу - таковы цели, декларируемые идеологиями коммунизма, либеральной демократии или свободного рынка. В свою очередь, витальная телеология отвечает реальности постмодерна с его фрагментированностью и релятивизмом - в отсутствии твердых ценностей жизнь остается единственной целью, достойной преследования; это, как минимум, дает надежду на ближайшее будущее, не простирающееся за пределы продолжительности человеческого века. Впрочем, витальная телеология попадала в поле зрения философии и ранее - например, тогда, когда формировалась конвенциональная концепция государства, создаваемого для защиты жизни как основополагающего блага ${ }^{5}$.

Сакральная телеология имеет отчетливо метафизический характер, а в секулярной телеологии могут быть обнаружены некоторые признаки метафизичности - постольку, поскольку из содержания целей, лежащих в ее основании, элиминирован религиозный гори- зонт смысла. Несмотря на это, они по-прежнему требуют веры в себя - если секулярные идеалы не будут опираться на уверенность в том, что цель достойна того, чтобы быть ценностью, то они моментально превратятся в мертвые формы смысла.

Кажется, что витальная телеология не имеет ничего, что могло бы сделать ее метафизической - однако это не так. Во-первых, с формальной точки зрения витальная телеология как принцип истолкования столь же далека от сциентистской парадигмы, как и секулярная и тем более сакральная, что делает ее метафизической по качеству. По содержанию же всякий витализм метафизичен постольку, поскольку понимает жизнь как процесс, подчиняющийся естественным законам, но не сводимый ни к ним в целом, ни к закону причинности в частности. Иными словами, витальная телеология оставляет больший простор для интерпретации того, какой должна быть эта жизнь (сравнительно с сакральной и секулярной телеологией), но это не делает ее неметафизической. По этой причине, несмотря на то что, как отмечает В.П. Зубков, «в настоящее время в науке уже весьма широко используются при описании самых разнообразных явлений такие понятия, как цель, телеологизм, системность, сложность, целесообразность, необратимость, случайность, онтология цели, направленность и др.» [Зубков $2012,43]$, это не вводит телеологию в предметное поле естествознания (и не повышает ее авторитет в глазах сциентизма). Причина этой неправомочности проста - телеологический подход к пониманию интеллигибельного и эмпирического мира культуры возможен потому, что при нем не происходит смешение природы мысли и вещей, когда в объективном существовании вещей нет ничего от идей, но с помощью первых можно делать суждения о вторых. Напротив, телеологические концепции объяснения природы, как отмечает Д.Н. Разеев [Разеев 2009, 83], не удовлетворяют принципу научности, т. к. вовлекают в естествознание чуждые ему принципы, не обладающие объективной (в сциентистском смысле) значимостью.

Помимо известной «метафизичности» сакральной, секулярной и даже, как оказывается, витальной телеологий, с точки зрения 
онтологии их объединяет интерес к проблеме осуществления цели, в процессе которого возможность становится действительностью. Г.В. Хлебников обозначает эту проблему следующим образом: «Телеология рассматривает категории возможности, деятельности и действительности в их противоречивом единстве и намечает связь этих категорий с понятиями “случайность” и “необходимость”» [Хлебников 2008, 147].

Если допустить, что феномены культурного пространства (где в конечном итоге и оказываются содержания творческого акта, ставшие фактом) могут иметь иную темпоральность, чем явления пространства эмпирического, то отношения между свободой (случайностью) и необходимостью будут иными. В литературе и кино нередко можно встретить сюжеты, связанные с путешествиями во времени. Это экстраординарное допущение радикально влияет на фабулу произведения - не только потому, что невозможное становится возможным, но и потому, что такой подход открывает интересные сюжетные перспективы. Примером может послужить новелла Р. Акутагавы «В чаще» (1922), предлагающая читателю три совершенно разных причинно-следственных последовательности для объяснения одного события. Новелла погружает читателя в прошлое, из которого будущее (в самом начале бывшее настоящим) меняется и приобретает иной вид. Это дает М.Е. Бойко основания утверждать, что «например, новелла Р. Акутагавы “В чаще”, рассказ Х.Л. Борхеса "Три версии предательства Иуды”, роман М. Павича “Хазарский словарь" имеют квантовую фабулу. А под квантовой фабулой мы понимаем линейное причинное течение событий сразу по нескольким альтернативным путям» [Бойко 2013, 32]. Не станем утверждать, насколько оправдано такое именование с точки зрения литературоведения. В контексте разбираемой здесь темы важно то, что «изменяя прошлое, путешественник во времени выступает как телеологическая причина, то есть будущее состояние системы влияет на ее прошлое состояние» [Бойко 2013, с. 33]. В связи с этим можно утверждать, что не только литературное произведение как феномен культуры, но и сама культура, и даже со- циальная реальность в целом подчиняются телеологической причинности настолько, насколько их можно понимать как нарратив. Другими словами, социальная реальность то же произведение, в котором из настоящего можно изменить понимание прошлого - paзумеется, не буквальным темпоральным перемещением, а метафорическим. Такую реальность ярко обрисовал Дж. Оруэлл; в ней факты вовсе не «упрямая вещь» и легко поддаются манипуляциям - настолько, что прошлое оказывается несостоятельным перед лицом нового настоящего. «...Было объявлено, что Океания с Евразией не воюет... Война идет с Остазией. Евразия - союзник. Океания воюет с Остазией: Океания всегда воевала с Остазией. Большая часть всей политической литературы последних пяти лет устарела. Всякого рода сообщения и документы, книги, газеты, брошюры, фильмы, фонограммы, фотографии - все это следовало молниеносно уточнить» [Оруэлл 2003, 232233]. Оруэлловское двоемыслие давно покинуло страницы художественной литературы и сделалось самостоятельным словом, дополняющим специальные термины вроде раздельного мышления-компартментализации и хорошо подходящим для описания тех состояний, в которые попадает сознание в результате агрессивных манипуляций, творящих новую реальность и изменяющих не только настоящее, но и прошлое.

Для творческого преобразования, каким бы «знаком», отрицательным или положительным, оно ни обладало, открыто все, что можно отнести к человеческой культуре. В свою очередь, оно детерминируется вопрошанием, традицией и целеполаганием, что делает возможным искать в нем телеологические акценты, ведь именно от них зависит интерпретация феноменов культурного пространства. По меткому замечанию И.А. Ильина, «в искусстве верно и художественно только необходимое» [Ильин 1992, с. 333]. Это характеризует свободу вопрошания как явление глубоко детерминированное. Но эта детерминированность состоит не в каких-либо внешних обстоятельствах и эмпирических причинах, она глубже и уходит своими истоками в интерес личности к явлению, на предмете которого задается вопрос к бытию о его возможности. 


\section{ПРИМЕЧАНИЯ}

${ }^{1}$ У Аристотеля можно найти четыре вида причин: «Причины... вещей в значении того, из чего эти вещи состоят; причем одни из них суть причины как субстрат (например, части), другиекак суть бытия вещи (таковы целое, связь и форма). С другой стороны... вообще то, что действует, - все это причины в смысле того, откуда начало изменения или покоя. А остальные суть причины в смысле цели и блага для другого, ибо “то, ради чего" должно быть наилучшим и целью для другого, причем пет никакой разницы, идет ли речь о подлинном благе или о кажущемся благе» [Аристотель 1976, 147]. Иными словами, Аристотель выделил материальную (субстрационную), формальную, действующую и целевую причинность.

${ }^{2}$ В.С. Степин, анализируя области применения различных типов причинности, отмечает, что для саморазвивающихся систем «уже не хватает ни вероятностной причинности, ни лапласовского детерминизма. Нужно ввести еще понятие целевой причинности» [Степин web].

${ }^{3}$ «Свобода есть дух, и дух есть свобода, но именно поэтому свобода умаляется и ущемляется по мере нисхождения к материальному плану жизни. Максимальная свобода существует для духовной жизни, для человеческой мысли и совести, для интимной жизни личности» [Бердяев 1994, 399].

${ }^{4}$ Поэтический пример такого мироощущения можно найти у Гесиода в рассказе о сменяющих друг друга эпохах. Вот его слова о прекрасном «золотом веке»:

Жили те люди, как боги, с спокойной и ясной душою, Горя не зная, не зная трудов. И печальная старость К ним приближаться не смела. Всегда одинаково сильны

Были их руки и ноги. В пирах они жизнь проводили. А умирали, как будто объятые сном. Недостаток

Был им ни в чем не известен. Большой урожай и обильный

Сами давали собой хлебодарные земли.

О скорбном «железном веке» сказано так: Землю теперь населяют железные люди. Не будет Им передышки ни ночью, ни днем от труда и от горя, И от несчастий. Заботы тяжелые боги дадут им. Чуждыми станут товарищ товарищу, гостю - хозяин, Больше не будет меж братьев любви, как бывало когда-то.

Старых родителей скоро совсем почитать перестанут; Будут их яро и зло поносить нечестивые дети

Тяжкою бранью, не зная возмездья богов; не захочет Больше никто доставлять пропитанья родителям старым.

Правду заменит кулак [Гесиод 2001, 55-56].
5 «Под благом (salus) же следует понимать не только простое сохранение жизни, какой бы она ни была, но, насколько это возможно, счастливую жизнь. Ведь люди добровольно объединились и установили государство именно для того, чтобы иметь возможность жить как можно счастливее, насколько это позволяют условия человеческого существования. Поэтому те, кто взял на себя отправление верховной власти в такого рода государствах, поступили бы против закона природы, обманув доверие тех, кто доверил им осуществление власти, если бы не стремились в дозволенных законами пределах в изобилии обеспечить граждан всеми благами, необходимыми не только для жизни, но и для удовольствия» [Гоббс 1989, 402].

\section{СПИСОК ЛИТЕРАТУРЫ}

Аристотель 1976 - Аристотель. Сочинения в четырех томах. Т. 1. М.: Мысль, 1976.

Бердяев 1994 - Бердяев Н.А. Основы богочеловеческой духовности. Философия свободного духа. М.: Республика, 1994.

Бойко 2013 - Бойко M.E. Обобщение теории фабулы: темпоральность, причинность, суперпозиция // Филологические науки. Вопросы теории и практики: в 2 ч. Ч. 1. 2013. № 11 (29). C. 31-34.

Бэкон 1977 - Бэкон Ц. Сочинения в двух томах. Т. 1 . М.: Мысль, 1977.

Бэкон 1978 - Бэкон Ц. Сочинения в двух томах. Т. 2 . М.: Мысль, 1978.

Гадамер 1991 - Гадамер Г.-Г. Актуальность прекрасного. М.: Искусство, 1991.

Гесиод 2001 - Гесиод. Труды и дни. М.: Лабиринт, 2001.

Гоббс 1989 - Гоббс Т. Сочинения в двух томах. Т. 1. М.: Мысль, 1989.

Дунаев 2008 - Дунаев А.Л. Основные этапы идеологической борьбы с ересью в XII-XIII вв. // Вестник Московского университета. Серия 8, История. 2008. № 1. С. 76-91.

Зубков 2012 - Зубков В.П. Детерминизм и телеология в современной философии науки // Новое в психолого-педагогических исследованиях. 2012. №4. С. 39-45.

Ильин 1992 - Ильин И.А. Путь к очевидности. М.: Республика, 1992.

Кант 1994 - Кант И. Сочинения в восьми томах. T. 5. М.: Чоро, 1994.

Кожев 2006 - Кожев A. Атеизм и другие работы. М.: Праксис, 2006.

Олар web - Олар Ф.А. Культ Разума и культ Верховного существа во время Французской революции // http://istmat.info/node/28905. 
Оруэлл 2003 - Оруэлл Дж. Скотный двор. 1984. Памяти Каталонии. Эссе. М.: АСТ, 2003.

Разеев 2009 - Разеев Д.Н. Критическая интерпретация кантовской аналитики телеологической способности суждения // Философские науки. 2009. № 11. C. 74-87.

Степин web-Cтепин В.С. Творчество А.А. Зиновьева и любовь к мудрости. Доклад на междунарудной конференции «Зиновьевские чтения в Московском университетете». 67 ноября 2008 г. // http://www.zinoviev.ru/ru/ conference/stepin.html.

Танхилевич 1926 - Танхилевич О.М. Эпикур и Эпикуреизм. М.: Новая Москва, 1926.

Терехович 2012 - Терехович В.Э. Действующие и целевые причины в принципе наименьшего действия // Вестник Ленинградского государственного университета им. А.С. Пушкина, 2012. № 3. T. 2. С. 49-59.

Фома Аквинский 2000 - Фома Аквинский. Сумма против язычников. Долгопрудный: Вестком, 2000.

Хлебников 2008 - Хлебников Г.В. Некоторые проблемы философской теологии Аристотеля, Платон и неоплатонизм (сводный реферат) // Социальные и гуманитарные науки. Отечественная и зарубежная литература. Серия 3, Философия. Реферативный журнал. 2008. № 2. C. $145-158$.

Bourg 2009 - Bourg D. L'impératifécologique// Esprit. 2009. № 360 (12). P. 59-71.

Elliott $2003-$ Elliott C. Humanity 2.0 // The Wilson Quarterly. 2003. Vol. 27, №. 4. P. 13-20.

Schrecker 1999 - Schrecker E. McCarthyism's Ghosts: Anticommunism and American Labor // New Labor Forum. 1999. № 4. P. 6-17.

\section{REFERENCES}

Aristotle, 1976. Collected Works: in 4 vols. Vol. 1. Moscow, Mysl' Publ.

Berdjaev N.A., 1994. Fundamentals of Divine-Human Spirituality. Free Spirit Philosophy. Moscow, Respublika Publ.

Bojko M.E., 2013. Generalization of the Theory of the Plot: Temporality, Causality, Superposition. Filologicheskie nauki. Voprosy teorii i praktiki: in 2 parts. Part 1, no. 11 (29), pp. 31-34.

Bacon F., 1977. Collected Works: in 2 vols. Vol. 1. Moscow, Mysl' Publ.

Bacon F., 1978. Collected Works: in 2 vols. Vol. 2. Moscow, Mysl' Publ.

Gadamer G.-G., 1991. The Relevance of the Beautiful. Moscow, Iskusstvo Publ.
Hesiod, 2001. Works and days. Complete collection of texts. Moscow, Labirint Publ.

Hobbes T., 1989. Collected Works: in 2 vols. Vol. 1. Moscow, Mysl' Publ.

Dunaev A.L., 2008. The Main Stages of the Ideological Struggle With Heresy in the $12^{\text {th }}-13^{\text {th }}$ centuries. Vestnik Moskovskogo universiteta. Series 8, History, no. 1, pp. 76-91.

Zubkov V.P., 2012. Determinism and Teleology in Modern Philosophy of Science. Novoe $v$ psihologo-pedagogicheskih issledovanijah, no. 4, pp. 39-45.

Il'in I.A., 1992. The Path to Evidence. Moscow, Republic Publ.

Kant I., 1994. Collected Works: in 8 vols. Vol. 5. Moscow, Choro Publ.

Kozhev A., 2006. Atheism and other works. Moscow, Praksis Publ.

Olar F.A., 1925. The Cult of Reason and the Cult of the Supreme Being During the French Revolution. Moscow, Sejatel' Publ. URL: http://istmat.info/ node/28905 (accessed 27 March 2019).

Orwell J., 2003. Barnyard. 1984. In Memory of Catalonia. Essay. Moscow, AST Publ.

Razeev D.N., 2009. Critical Interpretation of Kantian Analytics of the Teleological Ability of Judgment. Filosofskie nauki, no. 11, pp. 74-87.

Stepin V.S., 2008. Zinoviev and the Love of Wisdom. Report at the International Conference "Zinoviev Readings at Moscow University". November 6-7, 2008. URL: http: // www.zinoviev.ru/ru/conference/stepin.html (accessed 27 March 2019).

Tanhilevich O.M., 1926. Epicurus and Epicureanism. Moscow, Novaja Moskva Publ.

Terehovich V.E., 2012. Actual and Target Causes in the Principle of Least Action. Vestnik Leningradskogo gosudarstvennogo universiteta im. A.S. Pushkina, vol. 2 , no. 3, pp. 49-59.

Thomas Aquinas, 2000. Amount against Pagans. Book 1. Dolgoprudny, Vestkom Publ.

Hlebnikov G.V., 2008. Some Problems of Philosophical Theology of Aristotle, Plato and Neoplatonism (summary abstract). Social'nye i gumanitarnye nauki. otechestvennaja $i$ zarubezhnaja literatura. Serija 3, Filosofija. Referativnyj zhurnal, no. 2, pp. 145-158.

Bourg D., 2009. L'impératifécologique. Esprit, no. 360 (12), pp. 59-71.

Elliott C., 2003. Humanity 2.0. The Wilson Quarterly, vol. 27, no. 4, pp. 13-20.

Schrecker E., 1999. McCarthyism's Ghosts: Anticommunism and American Labor. New Labor Forum, no. 4, pp. 6-17. 


\section{Information about the Author}

Alexander V. Petrov, Candidate of Sciences (Philosophy), Associate Professor, Department of Philosophy and Political Science, Omsk Academy of the Ministry of Internal Affairs of the Russian Federation, Prosp. Komarova, 7, 644092 Omsk, Russian Federation, petrov.av.phd@gmail.com, https://orcid.org/0000-0001-8897-3066

\section{Информация об авторе}

Александр Викторович Петров, кандидат философских наук, доцент кафедры философии и политологии, Омская академия МВД России, просп. Комарова, 7, 644092 г. Омск, Российская Федерация, petrov.av.phd@gmail.com, https://orcid.org/0000-0001-8897-3066 